\title{
THE ROLE OF AGRITOURISM IN THE DEVELOPMENT OF LOW-CARBON DEVELOPMENT MODEL IN RURAL AREAS
}

\author{
ARKADIUSZ PIWOWAR \\ Wrocław University of Economics, POLAND \\ e-mail: arkadiusz.piwowar@ue.wroc.pl
}

RECEIVED
ACCEPTED
JEL
CLASSIFICATION

KEYWORDS agritourism, low emission economy, rural development, rural areas

ABSTRACT Agritourism is an important kind of economic activity in rural areas in Poland. The degree of development of agritourist services market in Poland makes it worthwhile to pay special attention to the role and importance of agritourism in shaping a low carbon economy in rural areas. In this work, which is a theoretical and pragmatic study, potential areas of resource-efficient and low-carbon activities in the field of tourism were outlined. According to the author, agritourist farms may be a significant element in the prosumer energy model in rural areas and serve as a model of conduct for the rural population. The owners of agritourism farms, who are often informal leaders of rural communities, are able to take environmental challenges and adapt to new circumstances. This can create an incentive and cause imitation effect among other residents of rural areas.

\section{Introduction}

Agritourism has different definitions (Arroyo, Barbieri, Rich, 2013; Broccardo, Culasso, Truant, 2017). The agritourism definition may depend on the geographical/contextual locality identified (Phillip, Hunter, Blackstock, 2010). B.J. Schilling, L.J. Marxen, H.H. Heinich, F.J.A. Brooks (2006) define agritourism "...as the business of establishing farms as travel destinations for educational and recreational purposes". Agritourism, as a form 
of rural tourism, is an important issue considered in the context of agribusiness in Poland. Rural tourism is defined as 'the overall tourism economy taking place in rural areas' (Wiatrak, 1996), while agritourism is a form of rural tourism closely related to the functioning of a farm (the use of residential buildings and/or farm buildings to provide accommodation services).

The concept of agritourism includes not only various forms of accommodation, catering and recreation services. An increasingly important element of the comprehensive service provided in the context of rural tourism is sport, and even healthcare and rehabilitation (Sznajder, Przebórska, 2006). From the point of view of economics, agritourism can be perceived in various areas, including:

- market, ie. the entirety of exchange relations between individuals and institutions, sellers of goods and agritourist services (supply) and the people and institutions acquiring them (demand),

- a form of rural development and the development of rural areas,

- economic activity of the rural population, manifested in creating and finding new sources of income,

- tourist activity of a man, associated with satisfying economic, social and cognitive needs. ${ }^{1}$

Tourism can play a significant role in addressing climate change (Yang, 2010). As it was indicated by J. Uglis and A. Jeczmyk (2015), agritourism is the area of economy, which at its basis is a stimulator of the sustainable development of the region, where economic, social and environmental aims are effectively realized. In this context, agritourism plays a crucial role, because in addition to accommodation, if offers a possibility of using numerous attractions associated with countryside and agriculture, for example, homemade meals using own products, mushroom picking, hunting, horse riding, etc. Currently, in the discussion of the scientific, political and economic life, growing importance of issues related to the reduction of $\mathrm{CO}_{2}$ emissions, renewable energy and low-carbon economy is frequently noted. In particular, the latter term is of particular importance, also in the field of agriculture. Low-carbon economy is defined as realizing the long-term growth and the most efficient use of resources, as well as aiming to minimize emissions of pollutants and its negative impact on the environment (Piontek, 2011; He, Wang, Yin, 2014). Climat change is the greatest challenge facing the future sustainability of tourism destinations (Becken, Hay, 2007). In this case agritourism can open new horizons in rural sustainable development. Developing lowcarbon eco-agricultural tourism is also a certain choice to achieve sustainable development of tourism industry (He, Wang, Yin, 2014). The essence of agritourism in the context of achieving the objectives of low-carbon economy has several dimensions, described in this article.

The aim of this study is to identify and characterised the areas of resource-efficient and low-carbon activities in the field of agritourism. Moreover, it outlined actions in these areas, enabling reduction in greenhouse gas emissions and improvement of the ability to absorb $\mathrm{CO}_{2}$, which can be widely used in planning the development of farms engaged in tourist activities.

\section{Areas of resource-efficient and low-carhon activities in the field of agritourism}

The challenges faced by agritourism in implementing the principles of sustainable development, including the pursuit of a low carbon economy, require special attention in several areas (Figure 1).

${ }^{1}$ The planes of the economic analyses in the field of agritourism presented above do not cover all that can be traced in the rich subject literature. 


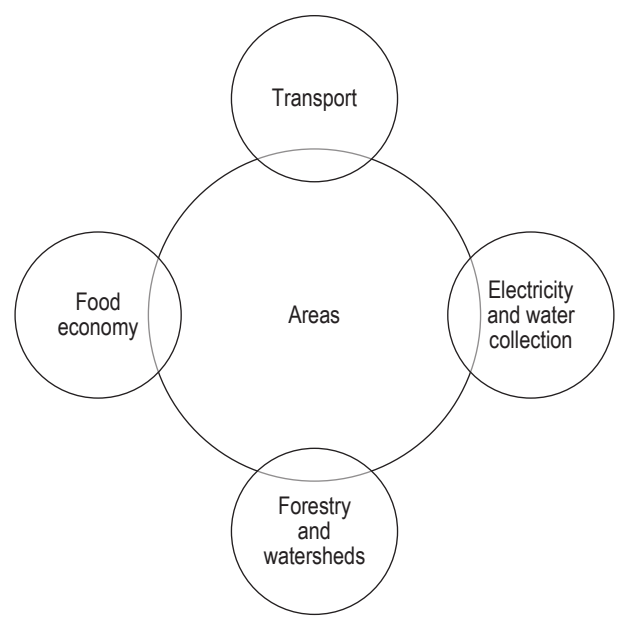

Figure 1. Potential areas of resource-efficient and low-carbon activities in the field of agritourism Source: own elaboration.

Agritourism is naturally associated with the limitation of the duration of stay, the need for individual and collective means of transport that use petroleum products as fuel. Agritourism gives the opportunity to rest to, among others, people from large agglomerations, exacerbated by the turmoil of the cities. They will often seek contact with nature and relaxation. Depending on the circumstances, agritourism uses different means of transport, including living beings (horses), technical measures for river tourism (e.g. canoes), hiking (observation of flora and fauna, learning about cultural values), bicycles, cross country skiing, etc. Means of transport, alternative to cars, undoubtedly contribute to a resource-efficient and low-carbon local economy. Automotive transport is in fact one of the main sources of pollution and greenhouse gas emissions. From the point of view of development prospects and technical progress, the future attractions in agro-tourism may include, for example, electric vehicles (scooters, bikes, cars, etc.). This requires adequate road infrastructure, construction (reconstruction) of biking and hiking paths (pavement, lighting, etc.).

Agritourism is a complex and multifaceted activity, it is associated with taking (especially during high demand period) significant costs associated with the consumption of electricity and water intake. Energy efficiency may involve, among others, using devices for solar energy conversion (e.g. solar micro-installations). It is important that the solar cells convert electrical energy without the production of secondary pollutants and noise. The lack of factors causing adverse effects in the environment due to photovoltaic installations creates great potential for their use in agritourism. Photovoltaic installations of larger sizes, forming a network (photovoltaic farms) may provide additional tourist attraction in rural areas. In case of agritourism facilities located far from the power grid (mountain chalets, forest cottages, etc.), photovoltaics can be a primary source of energy. Due to climatic conditions in the area of Poland solar systems in agritourism may be mainly used to heat water for utility purposes (in residential premises) and for agricultural purposes. Examples of the use of solar collectors in agritourism farms are described in the literature, including the works by A. Kowalczyk-Juśko, B. Kościk and J. Tenet (2016). According to the results of surveys conducted by other authors, tourist facilities should use eco-energy, and the service recipients would be even willing to pay more for the service that contributes to improving the environment (Sokół, 2012). 
Also biomass can be used for energy purposes in agritourism farms (Piwowar, Dzikuć, Adamczyk, 2016). Biogas micro installation may serve as the security pillars of energy supply of agritourism farm. In Poland there are also geothermal sources, which can be used for space heating needs (construction of geothermal plants), and in the case of agritourism, also in balneology. As it was indicated by B. Dec and J. Krupa (2014), these may be medicinal baths useful in many diseases, including orthopaedic, nervous and circulatory diseases, neuroses and neuralgia.

In turn, the reduction of water consumption requires changes in habits (adjustments of water stream) and the use of appropriate tools. Tourists should be informed about the principles of environmental protection and educated in the scope of observance of ecological behaviour. With regard to the equipment, important elements may be mixing faucets with Eco function, thermostatic and non-contact ones. Reducing of water consumption is important not only in regard to potable water, but also in case of water for economic purposes. In the latter case, the basic elements of the equipment are rainwater tanks. In an assortment of many manufacturing and trading enterprises in Poland there are available rainwater underground tanks and decorative tanks (different shapes, colours, etc.), allowing you to match the right solution to explicit tasks and needs of the specific agritourism farm.

The priority in efforts to protect the climate and in the transition to a low carbon economy is to preserve (protect) forests. Forests provide many valuable raw materials for agribusiness (wood, fruit and mushrooms, herbal materials), they are also an essential element of agritourism service (Piwowar, 2015). According to J. Cichowska (2011), forest areas will play an increasingly important role in building "agritourism packages". The author recognizes the positive role of the forest in the upbringing and education, which may have an impact on the evolution of environmentally friendly attitudes among guests staying at rest. Forests are often a place of specialized forms of activity within the agritourism services, such as, among others, walks, mushroom and berry picking, watching forest animals. In the opinion of T. Dziechciarz (2011), the development specialized agritourism in forest areas of eastern Poland promotes comprehensive protection of natural environment. In the literature, the impact of water basins on the attractiveness of agritourism service is also recognised (Bielak, 2007).

Another potential area of resource-efficient and low-carbon activities in the field of agritourism is the food economy, and within it mainly agriculture. Agritourism offer is often associated with a specific system of farming - organic (Piwowar, 2017). In the system of organic farming the system of recirculated substance within the farm is used as well as avoiding the use of synthetic chemicals (fertilizers, pesticides). This is management consistent with the natural processes occurring in environment, which does not disturb the ecological balance. In these farms, particular attention is paid to the conservation of biodiversity. In the course of agritourism business, it is often made possible to buy milk and products from the farm. Direct sales of agricultural products in agritourism farms are an important source of income for farmers and other rural residents. Organic and / or traditional food sold in short supply chains supports key elements of sustainable rural economy. The result is the relationship between local agriculture, tourism and the food sector. In addition, direct selling allows the customers to obtain information about the product and how it is obtained. Food prepared according to the natural, traditional recipe, is an important element in the development of local food markets.

The abovementioned elements of resource-efficient and low-carbon activities in the field of agritourism do not exhaust the subject. They form the basis for further research and discussion (in the field of waste management, thermal modernization, etc.). 


\section{Conclusions}

The development of agritourism is related to the attractiveness of the area and the organization and management of resources available at the disposal of service providers. Agritourism essentially provides visitors the opportunity to temporarily stay in the uncontaminated area. The development of agritourism should be planned and sustainable in its nature, it must be made in harmony with the environment, which means the limitation of various types of emissions (direct and indirect). Potential areas of resource-efficient and low-carbon activities in the field of agritourism are: transport, electricity and water consumption, forestry and water tanks as well as food economy.

Theoretical and practical analysis lead to the conclusion that agritourism plays a significant role in shaping a low-carbon model of development in rural areas. The examined issue is associated with the transformation of the economic and energy-ecological Polish village in the direction to low-carbon economy. The development of such economy in rural areas requires the implementation of low-carbon technologies and practices as well as efficient energy solutions not only in the production field, but also in other activities in rural areas. The owners of agritourism farms, who are often informal leaders of rural communities, are able to take environmental challenges and adapt to new circumstances. This can create an incentive and cause imitation effect among other residents of rural areas. Due to the dynamic development of agritourism services in Poland, this market should be an important area of interest in shaping a low carbon economy in rural areas.

\section{Acknowledgment}

Article funded by the National Science Centre from the funds for science within research project in the field of basic research - Sonata No. 2016/21/D/HS4/00087, entitled "The state and prospects of the development of low-carbon agriculture in Poland and the behaviour of agricultural producers".

\section{References}

Arroyo, C., Barbieri, C., Rich, S.R. (2013). Defining Agritourism: A Comparative Study of Stakeholders' Perceptions in Missouri and North Carolina. Tourism Management, 37, 39-47.

Becken, S., Hay, J.E. (2007). Tourism and Climate Change: Risk and Opportunities. Clevedon: Channel View Publications.

Bielak, B. (2007). Turystyka w otoczeniu zbiorników zaporowych na Dunajcu. Prace Geograficzne, 117, 13-27.

Broccardo, L., Culasso, F., Truant, E. (2017). Unlocking Value Creation Using an Agritourism Business Model. Sustainability, 9, 1618.

Cichowska, J. (2011). Rola lasu i zbiorników wodnych w rozwoju usług agroturystycznych. Infrastruktura i Ekologia Terenów Wiejskich, 10, 29-42.

Dec, B., Krupa, J. (2014). Wykorzystanie odnawialnych źródeł energii w aspekcie ochrony środowiska. Przegląd Naukowo-Metodyczny „Edukacja dla Bezpieczeństwa”, 7, 722-757.

Dziechciarz, T. (2011). Agroturystyka wyspecjalizowana na obszarach leśnych (na przykładzie Lasów Janowskich). Studia i Materiały CEPL w Rogowie, 3, 301-306.

He, J.B., Wang, Z., Yin, Q.L. (2014). On Sustainable Development of Eco-Agricultural Tourism in Low-Carbon Economy. Advanced Materials Research, 869, 946-949.

Kowalczyk-Juśko, A., Kościk, B., Teneta, J. (2016). The use of renewable energy resources in selected tourist facilities. Economic and Regional Studies, 9 (1), 77-85.

Phillip, S., Hunter, C., Blackstock, K. (2010). A typology for defining agritourism. Tourism Management, 31, 754-758.

Piontek, W. (2011). Fundusze strukturalne jako instrument wsparcia rozwoju gospodarki niskoemisyjnej i zasobooszczędnej. Białystok: Wydawnictwo Wyższej Szkoły Ekonomicznej w Białymstoku.

Piwowar, A. (2015). Zasoby leśne - baza surowcowa i znaczenie w agrobiznesie. Journal of Agribusiness and Rural Development, 1, 99-104. 
Piwowar, A. (2017). Integrated and ecological agriculture as an element of the development of low carbon agricultural economy in Poland. In: W. Wawrzyniak, R. Woźniak, T. Zaborowski (eds.), Socio-Economics Borderland (pp. 113-124). Gorzów WielkopolskiPoznań: Instytut Badań i Ekspertyz Naukowych w Gorzowie Wlkp.

Piwowar, A., Dzikuć, M., Adamczyk, J. (2016). Agricultural biogas plants in Poland - selected technological, market and environmental aspects. Renewable \& Sustainable Energy Reviews, 58, 69-74.

Schilling, B.J., Marxen, L.J., Heinich, H.H., Brooks, F.J.A. (2006). The opportunity for agritourism development in New Jersey (Rutgers Univ. Food Policy Inst. Publ. No. 0706-010). Retrieved from: http://www.nj.gov/agriculture/pdf/ATReport.pdf (30.01.2018).

Sokół, J.L. (2012). Wykorzystanie odnawialnych źródeł energii w turystyce na przykładzie województwa podlaskiego. Economy and Management, 2, 39-55.

Sznajder, M., Przezbórska, L. (2006). Agroturystyka. Warszawa: PWE.

Uglis, J., Jęczmyk, A. (2015). Agroturystyka jako faktor zrównoważonego rozwoju. Prace Naukowe Uniwersytetu Ekonomicznego we Wrocławiu, 379, 57-66.

Wiatrak, A.P. (1996). Wpływ agroturystyki na zagospodarowanie obszarów wiejskich. Zagadnienia Ekonomiki Rolnej, 1, 35.

Yang, W. (2010). The development of tourism in the Low Carbon Economy. International Business Research, 3 (4), 212-215.

Cite this article aS: Piwowar, A. (2018). The role of agritourism in the development of low-carbon development model in rural areas. European Journal of Service Management, 3 (27/1), 217-222. DOI: 10.18276/ejsm.2018.27/1-27. 